\title{
Radiological Abnormalities and Asymptomatic Bacteriuria in Patients with Sickle Cell Disease
}

BF Morrison ${ }^{1}$, D Cornwall ${ }^{1}$, W Madden², P Johnson ${ }^{1}$, M Didier ${ }^{1}$, M Reid $^{2}$

\begin{abstract}
Objective: The prevalence of asymptomatic bacteriuria (ASB) in sickle cell disease (SCD) in Jamaica is 5.3\%. This study sought to determine the association between ASB and anatomical urological abnormalities and symptomatic urinary tract infections (UTIS).

Methods: A matched case-controlled study of 11 patients with a history of ASB from the Jamaican Sickle Cell Cohort and 11 controls who did not have a history of ASB or recurrent UTIS but who had SCD was conducted. Midstream urine collected aseptically was obtained for urinalysis and culture and sensitivity analysis. Serum creatinine was measured. Voiding cystourethrogram (VCUG) and kidney-ureter-bladder ultrasound were done. History of UTIs was recorded in all cases.

Results: The mean \pm sd age of the group (cases and controls) was $34.2 \pm 7.2$ years. All VCUGs were normal. There was no difference in mean cortical thickness or renal scarring between cases and controls. All serum creatinine values were normal: cases (mean $\pm s d: 55.9 \pm 15.3$;

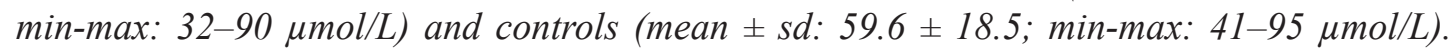
There was no difference in symptomatic UTIs between cases and controls.

Conclusion: There was no association between anatomical urinary tract abnormalities and ASB in patients with SCD. Asymptomatic bacteriuria in SCD was not associated with increased numbers of symptomatic UTIs.
\end{abstract}

Keywords: Bacteriuria, sickle cell anaemia, ultrasonography, urinary tract infections, vesico-ureteral reflux

\section{Anormalidades radiológicas y bacteriuria asintomática en pacientes con la enfermedad de células falciformes}

BF Morrison ${ }^{1}$, D Cornwall ${ }^{1}$, W Madden², P Johnson ${ }^{1}$, M Didier ${ }^{1}$, M Reid ${ }^{2}$

\section{RESUMEN}

Objetivo: La prevalencia de bacteriuria asintomática (BAS) en la enfermedad de células falciformes (ECF) en Jamaica es $5.3 \%$. Este estudio tuvo por objeto determinar la asociación entre $B A S$ y las anormalidades anatómicas urológicas, y las infecciones del tracto urinario (ITU). Métodos: Se realizó un estudio de casos y controles pareado de 11 pacientes con una historia de BAS de la cohorte de células falciformes de Jamaica, y 11 controles que no tenían antecedentes de BAS o infecciones recurrentes del tracto urinario, pero que padecian de ECF. Una

From: ${ }^{1}$ Department of Surgery, Radiology, Anaesthesia and Intensive Care, The University of the West Indies, Mona, Jamaica, West Indies and ${ }^{2}$ Sickle Cell Unit, Tropical Medicine Research Institute, The University of the West Indies, Mona, Jamaica, West Indies.
Correspondence: Dr B Morrison, Department of Surgery, The University of the West Indies, Mona, Kingston 7, Jamaica, West Indies. Email: belinda.morrison02@uwimona.edu.jm 
muestra de orina limpia a mitad de la micción fue recogida asépticamente para el análisis de orina, el urocultivo, y el análisis de sensibilidad. Se midió la creatinina sérica. Se hizo un cistouretrograma de evacuación (CUGE) y un ultrasonido de riñón-uréter-vejiga. Se hicieron historias clínicas de las infecciones urinarias en todos los casos.

Resultados: La edad media \pm sd del grupo (casos y controles) fue de $34.2 \pm 7.2$ años. Todos los cistouretrogramas (CUGE) resultaron normales. No hubo diferencias en el grosor cortical medio o la cicatrización renal entre los casos y los controles. Todos los valores de la creatinina sérica fueron normales: los casos (promedio \pm sd: $55.9 \pm 15.3$; min-max: 32-90 $\mu \mathrm{mol} / \mathrm{L}$ ), y los controles (promedio $\pm s d: 59.6 \pm 18.5$; min-max: 41-95 $\mu \mathrm{mol} / \mathrm{L}$ ). No hubo diferencias en las ITU sintomáticas entre casos y controles.

Conclusión: No hubo asociación alguna entre las anormalidades anatómicas del tracto urinario y BAS en los pacientes con ECF. La bacteriuria asintomática en la ECF no estuvo asociada con el aumento del número de ITU sintomáticas.

Palabras clave: Bacteriuria, anemia de células falciformes, ultrasonografía, infecciones del tracto urinario, reflujo vesicoureteral

\section{West Indian Med J 2017; 66 (4): 498}

\section{INTRODUCTION}

Asymptomatic bacteriuria (ASB) is defined as the isolation of a specified quantity of bacteria in an appropriately collected urine specimen obtained from a person without symptoms or signs referable to a urinary tract infection [UTI] (1). High-risk persons for ASB include diabetics, elderly persons living in the community or institutions, patients with spinal cord injury and persons with indwelling urethral catheters (2). Asymptomatic bacteriuria is also common in sickle cell disease [SCD] (3). Screening for and treatment of ASB is only recommended in pregnant women or prior to transurethral resection of the prostate or any urological invasive procedure for which mucosal bleeding is expected (4). In these two patient populations, treatment of ASB reduces the risk of pyelonephritis and sepsis $(5,6)$.

The clinical relevance of ASB in SCD is frequently questioned by physicians. Urinary tract infections are common in patients with SCD (7). These symptomatic infections are a cause of great morbidity with increasing frequency of painful crises and other infectious complications (8). Renal disease is also common in SCD and may be associated with symptomatic or asymptomatic UTIs (9). Asymptomatic bacteriuria in SCD increases the risk of symptomatic UTIs (10). However, ASB in the absence of anatomical or functional urinary tract abnormalities is not associated with renal dysfunction (11). It is uncertain if ASB in SCD may ultimately lead to renal disease. We sought to determine the relationship between ASB in SCD and anatomical urinary tract abnormalities. In addition, we sought to determine the long-term outcome of patients with ASB, with respect to symptomatic UTIs.

\section{SUBJECTS AND METHODS}

The study was a case-control study conducted at the Sickle Cell Unit. The study population comprised 22 patients: 11 cases and 11 controls who were age-matched in a 1:1 ratio. All patients were asymptomatic of UTIs at the time of the study. All patients attended the ambulatory clinic at the Sickle Cell Unit, which is a non-referral unit, and any patient with any of the sickle cell diseases who wished to participate was registered and provided with clinical care.

The Sickle Cell Cohort comprised patients with sickle cell diseases detected using standard criteria on screening 100000 non-operative deliveries in the largest maternity unit in Jamaica between 1973 and 1981 (12). The screening yielded 580 infants with various sickle genotypes, with 315 having the homozygous genotype (HbSS). The cohort was followed annually.

In 2004, 266 persons attending the annual cohort review consented to a cross-sectional study investigating ASB in SCD. Of these persons, 14 were confirmed to have ASB. Three of these patients were lost to followup. However, 11 of these consented, as cases, for this study conducted from October 1 to 31, 2010.

Controls were patients who did not have a history of ASB or recurrent UTIs but who had homozygous sickle cell anaemia ( $\mathrm{HbSS})$. Eligible controls were 
randomly chosen from the electronic database at the Sickle Cell Unit.

Patients with acute illnesses were excluded. Patients complaining of symptoms suggestive of a UTI were not screened for ASB on that day.

Asymptomatic bacteriuria was defined by the presence of at least $10^{5}$ colony-forming units of the same uropathogen per milliliter of midstream urine (MSU) specimen with similar sensitivity profiles in two consecutive cultures obtained from an asymptomatic patient. Contamination was identified by the presence of more than two uropathogens.

Exposure status was classified as the presence or absence of abnormalities on kidney-ureter-bladder (KUB) ultrasound and voiding cystourethrograms (VCUG).

Urinalysis and microscopy were performed on small aliquots of the MSU on the same day. Proteinuria was defined as the presence of a trace or greater protein on urine microscopy. Microscopic haematuria was defined as the presence of more than two red blood cells per high power field on microscopy.

Midstream urine samples were collected aseptically in all patients and sent for microbiological culture and sensitivity on the same day. Bacterial culture was performed by streaking $0.002 \mathrm{~mL}$ of MSU with a calibrated loop on MacConkey and 5\% sheep blood agar plates. These agar plates were incubated at $35^{\circ} \mathrm{C}$ for 24 hours under aerobic conditions. Significant isolates were selected for identification and antimicrobial susceptibility testing using VITEK $^{\circledR}$ (bioMérieux version R06.01, Missouri, United States of America). All abnormal MSU samples were repeated for confirmation of ASB. No patient was symptomatic of a UTI at the time of testing.

Blood samples were also taken for the measurement of serum creatinine using the enzymatic VITROS ${ }^{\circledR} 350$ assay. All samples were tested at a central laboratory. The VITROS CREA slide method was employed which used a multi-layered, analytical element coated on a polyester support. This employed an enzymatic method of determining creatinine levels in the ranges of 4-1238 $\mu \mathrm{mol} / \mathrm{L}(0.05-14.0 \mathrm{mg} / \mathrm{dL})$ in serum.

All patients had a KUB ultrasound and standard fluoroscopic contrast VCUG performed by a single radiologist who was blinded to the case or control status of the patients. Kidney-ureter-bladder ultrasound was done using a GE LOGIQ ${ }^{\circledR} 500$ pro series machine to evaluate for renal size (length in $\mathrm{cm}$ ), renal cortical scars, parenchymal cortical thickness, hydronephrosis, renal parenchymal disease, bladder wall thickness, post void residual volume or any other abnormalities. Voiding cystourethrograms were performed using a Philips Eleva ${ }^{\circledR}$ digital fluoroscopy unit to determine the presence of vesico-ureteric reflux. Patients with confirmed ASB were given prophylactic antibiotics for the procedure. Patients were catheterized under sterile conditions prior to the procedure and the bladder emptied. High osmolar contrast material was instilled via the catheter into the bladder until it was completely distended on intermittent fluoroscopic visualization. A pre-contrast installation coned view of the bladder was obtained. Once bladder distention was complete, the catheter was removed and the patient positioned in an anterior oblique position. Once micturition was complete, a full length view of the abdomen was taken to show undetected reflux at the level of the kidneys and the post micturition residue.

Chart review was performed to determine any additional chronic medical illness or condition that could impair voiding.

In 2016, the charts of all patients who consented to the study were reviewed to determine the diagnoses of symptomatic UTIs and ASB since the measurements in 2010.

Patients attending the Sickle Cell Unit regularly utilize the ambulatory clinic for any medical complaint. Reports of symptomatic UTIs from the Sickle Cell Unit would reliably report all episodes occurring during the study period. Records were also reviewed to determine any new diagnoses such as renal impairment.

Ethical approval was granted for this study by the University Hospital of the West Indies/The University of the West Indies, Mona, Faculty of Medical Sciences Ethics Committee, and the study was conducted in accordance with the Declaration of Helsinki of 1975.

Summary values were expressed as counts or mean \pm sd as appropriate. The Wilcoxon rank sum test was used to compare differences in medians between cases and controls. Differences between cases and controls were examined with the Chi-square test for categorical variables. The odds ratio of exposure to radiological abnormalities in cases versus controls was calculated. A $p$ value of $<0.05$ was considered significant. Data were analysed using Stata 12 for Windows (College Station, United States of America).

\section{RESULTS}

The mean \pm sd age of the group was $34.2 \pm 7.2$ years. Cases consisted of 11 female patients, and controls were 10 female patients and 1 male patient. All female patients were non-pregnant at the time of the study, and 
no patient had any other chronic medical illness. No patient had an indwelling catheter or performed clean intermittent catheterization. There was no difference in the mean age between cases and controls (Table).

Prevalence of bacteriuria: there was confirmed ASB in two (18\%) of the cases and none of the controls. The isolated organisms were Escherichia coli and Klebsiella ozaenae. Sensitivity pattern of the isolated organisms showed $100 \%$ sensitivity to furadantin, cefuroxime, norfloxacin, augmentin and cotrimoxazole.

Urinalysis and microscopy: microscopic haematuria was present in one case. Mild proteinuria was present in four patients (three cases and one control). Calcium oxalate crystals were detected on urinalysis in two cases and uric acid crystals in one case and one control.

Creatinine: all serum creatinine values were normal: cases (mean \pm sd: $55.9 \pm 15.3$; min-max: $32-90 \mu \mathrm{mol} / \mathrm{L}$ ) and controls (mean \pm sd: $59.6 \pm 18.5$; min-max: 41-95 $\mu \mathrm{mol} / \mathrm{L}$ ). There was no significant difference between serum creatinine levels in cases and controls: $p=0.6$.

Ultrasound findings: the mean renal cortical thickness was $2.7 \pm 0.37 \mathrm{~cm}$ and $2.0 \pm 0.47 \mathrm{~cm}$ for right and left kidneys in controls $(p=0.53)$ and $2.7 \pm 0.4 \mathrm{~cm}$ and $2.2 \pm 0.59 \mathrm{~cm}$ in cases $(p=0.40)$.

There were no significant differences in renal scarring or renal lengths between cases and controls.

Unilateral renal scarring was noted in one case who had ASB confirmed in 2010. Renal scarring was also noted in one control. There was no evidence of renal parenchymal disease in any patient. Post-void residual volume was negligible in all patients. Mild hydronephrosis was detected in two controls and a small asymptomatic calculus in one case. No other abnormalities were detected.

$V C U G$ findings: all VCUGs were normal. No vesicoureteric reflux was detected in either cases or controls.
Urinary tract infections: there was no significant difference in the numbers of symptomatic UTIs based on ASB status $(p=0.6)$. Two cases and three controls reported symptomatic UTIs since the study in 2010 . Of these, one case who had documented ASB in 2004 and 2010 reported three symptomatic UTIs over the fiveyear period. This patient also had right renal scarring on ultrasound. Another case reported two symptomatic UTIs over the same period. All other reported UTIs were solitary infections over five years. The isolated organism in all cases was Escherichia coli. There were no reported or recorded episodes of febrile UTIs.

Renal impairment: no diagnosis of renal impairment was made in either cases or controls on chart review in 2016.

\section{DISCUSSION}

The study showed that there was no association between anatomical urinary tract abnormalities and ASB in patients with SCD. Persistent ASB was detected in only $18 \%$ of cases who demonstrated ASB in the initial study in 2004. There was no significant difference in the numbers of symptomatic UTIs in patients with a history of ASB compared to those without.

The prevalence of ASB in SCD is reported to range from $4 \%$ to $6.6 \%(3,10,13,14)$. This rate does not appear to differ significantly from the reported prevalence rate of $5 \%$ in healthy premenopausal women without SCD (15). However, in several series, the prevalence rate of ASB in SCD is reported to be significantly greater than that in controls without SCD (3). This disparity in prevalence rates may be related to factors such as the age, gender and sexual activity of the patients. The prevalence of ASB increases with age and sexual activity and is rare in young men (16-18). Studies reporting on the prevalence of ASB in SCD were varied with several

Table: Differences in exposure status and baseline parameters between cases and controls

\begin{tabular}{llll}
\hline Clinical variable & Case (n) & Control (n) & $\boldsymbol{p}$ value \\
\hline Renal abnormality & 1 & 3 & $0.27(0.004,4.32)^{*}$ \\
Hydronephrosis & 0 & 2 & \\
Renal scar & 1 & 1 & \\
Age (years) & $34.3(2.5)^{* *}$ & $33.9(10.1)^{* *}$ & 0.4 \\
Males & 0 & 1 & 1.0 \\
Serum creatinine & 55.9 & $59.6(18.5)^{* *}$ & 0.6 \\
( $\mu$ mol/L) & $(15.3)^{* *}$ & & \\
UTIs since 2010 & 2 & 3 & 0.6 \\
\hline
\end{tabular}

* Odds ratio (confidence interval)

** Mean (SD) 
including only children $(3,14)$, whereas others had a mixed sample of both young males and females $(10,13)$.

To our knowledge, this is the first study in a population of patients with SCD evaluating an association between anatomical urinary tract abnormalities and ASB. Very few studies have evaluated ASB and anatomical or functional urinary tract abnormalities in varied patient populations. However, few studies have been reported on ASB in the neurogenic bladder or the patient with spinal cord injury $(19,20)$. A VCUG was done primarily to assess for the presence of vesico-ureteric reflux, and this was not demonstrated in any of our patients. Vesico-ureteric reflux may lead to upper UTIs and possible renal scarring in patients with symptomatic lower UTIs. However, ASB in the absence of reflux has not been proven to lead to renal scarring (11). In a sample of patients with ASB and neurogenic bladders secondary to spina bifida who performed clean intermittent self-catheterization, it was reported that in the absence of vesico-ureteric reflux, there was no significant renal scarring demonstrated on technetium 99 m dimercaptosuccinic acid (DMSA) scans (11). These patients were therefore spared antibiotic prophylaxis, which appeared to confer no benefit. A KUB ultrasound was done to assess for the presence of renal scars or renal parenchymal loss that could be related to upper UTIs. We acknowledge the limitation of the reduced sensitivity of KUB ultrasound in assessing renal scarring compared to DMSA renal scans. However, ultrasounds were more readily available and cost-effective in our clinical scenario. The absence of a difference in renal scarring in cases versus controls is supportive of a lack of adverse effects of ASB in patients with SCD. Though serum creatinine is not a sensitive marker of early renal impairment, our results suggest no biochemical impairment in renal function between cases and controls. This was previously reported in an earlier paper in 2004 (10).

Asymptomatic bacteriuria did not appear to be persistent in the 11 cases who were initially diagnosed in 2004, with only two (18\%) patients having documented ASB in 2010. This was similar to the report of Adegoke where only 2 of 13 patients had persistent ASB after six months of follow-up (14). The lack of persistence of ASB perhaps suggests the transitory nature of the diagnosis and further underscores the lack of guidelines supporting screening or implementation of antibiotic therapy in patients with SCD and ASB. Asymptomatic bacteriuria is also rarely persistent in young, healthy women. In a large prospective study of young females, episodes of ASB lasting more than two months were seen in less than $1 \%$ of the females studied (15). Persistent bacteriuria with the same strain of organism was also rare suggesting a transitory nature of ASB in young females.

In young women without SCD, ASB appears to be a predictor of subsequent UTIs (15). In a large cohort of women of 18-40 years of age recruited from a university health centre and health maintenance organization, ASB was found to significantly increase the risk of subsequent UTIs in one week and one month (15). There are inconsistent results on the association between ASB and subsequent symptomatic UTIs in patients with SCD. Cumming et al documented a 2.5-fold increase in the number of symptomatic UTIs in patients with SCD with a diagnosis of ASB compared to those without ASB (10). Our results demonstrated no difference in the numbers of symptomatic infections in cases compared to controls over six years. In fact, UTIs documented in cases did not fulfil the classification of recurrent UTIs, where more than three infections were documented in 12 months (21). Adegoke also failed to show new symptomatic UTIs in 13 patients with ASB and SCD after six months of follow-up (14).

This study is limited by its small sample size which affects generalizability of the results. However, there is a benefit that the cases belonged to the Sickle Cell Cohort where the sample was highly representative of the sickle cell population and compliance with clinic reviews was high with reliable and comprehensive follow-up data. We did not assess functional lower urinary tract abnormalities with urodynamics due to resource constraints. Functional urinary tract abnormalities may exist in the absence of anatomical abnormalities and may have an impact on lower UTIs. We did not assess for the potential confounder of sexual activity.

Several authors have suggested screening for and treatment of ASB in SCD due to its apparent high prevalence. The accumulated evidence demonstrating the transient nature of ASB in SCD as well as the absence of long-term renal impairment or associated urinary anatomical abnormalities do not support screening for and treatment of the diagnosis. Screening can be considered only if antimicrobial treatment will alter adverse outcomes in the screened population. We must be mindful of the need for antimicrobial stewardship, particularly where there is the potential of adverse effects and bacterial resistance. Further prospective studies with large populations are needed to determine the clinical significance of ASB in SCD. 


\section{CONCLUSION}

There was no association between anatomical urinary tract abnormalities and ASB in patients with SCD. Asymptomatic bacteriuria in SCD was not associated with increased numbers of symptomatic UTIs.

\section{REFERENCES}

1. Rubin RH, Shapiro ED, Andriole VT, Davis RJ, Stamm WE. Evaluation of new anti-infective drugs for the treatment of urinary tract infection. Infectious Diseases Society of America and the Food and Drug Administration. Clin Infect Dis 1992; 15 Suppl 1: S216-27.

2. Colgan R, Nicolle LE, McGlone A, Hooton TM. Asymptomatic bacteriuria in adults. Am Fam Physician 2006; 74: 985-90.

3. Chukwu BF, Okafor HU, Ikefuna AN. Asymptomatic bacteriuria in children with sickle cell anemia at The University of Nigeria teaching hospital, Enugu, South East, Nigeria. Ital J Pediatr 2011; 37: 45.

4. Nicolle LE, Bradley S, Colgan R, Rice JC, Schaeffer A, Hooton TM et al. Infectious Diseases Society of America guidelines for the diagnosis and treatment of asymptomatic bacteriuria in adults. Clin Infect Dis 2005; 40: 643-54.

5. Smaill F. Antibiotics for asymptomatic bacteriuria in pregnancy. Cochrane Database Syst Rev 2001: CD000490.

6. Grabe M, Forsgren A, Bjork T, Hellsten S. Controlled trial of a short and a prolonged course with ciprofloxacin in patients undergoing transurethral prostatic surgery. Eur J Clin Microbiol 1987; 6: 11-7.

7. Wierenga KJ, Hambleton IR, Wilson RM, Alexander H, Serjeant BE, Serjeant GR. Significance of fever in Jamaican patients with homozygous sickle cell disease. Arch Dis Child 2001; 84: 156-9.

8. Magnus SA, Hambleton IR, Moosdeen F, Serjeant GR. Recurrent infections in homozygous sickle cell disease. Arch Dis Child 1999; 80: 537-41.

9. Saborio P, Scheinman JI. Sickle cell nephropathy. J Am Soc Nephrol 1999; 10: 187-92.
10. Cumming V, Ali S, Forrester T, Roye-Green K, Reid M. Asymptomatic bacteriuria in sickle cell disease: a cross-sectional study. BMC Infect Dis 2006; 6: 46

11. Ottolini MC, Shaer CM, Rushton HG, Majd M, Gonzales EC, Patel KM. Relationship of asymptomatic bacteriuria and renal scarring in children with neuropathic bladders who are practicing clean intermittent catheterization. J Pediatr 1995; 127: 368-72.

12. Serjeant GR, Serjeant BE, Forbes M, Hayes RJ, Higgs DR, Lehmann H. Haemoglobin gene frequencies in the Jamaican population: a study in 100000 newborns. Br J Haematol 1986; 64: 253-62.

13. Akinbami AA, Ajibola S, Bode-Shojobi I, Oshinaike O, Adediran A, Ojelabi $\mathrm{O}$ et al. Prevalence of significant bacteriuria among symptomatic and asymptomatic homozygous sickle cell disease patients in a tertiary hospital in Lagos, Nigeria. Niger J Clin Pract 2014; 17: 163-7.

14. Adegoke SA, Adegun PT. Asymptomatic bacteriuria in Nigerian children with sickle cell anemia. Indian J Nephrol 2013; 23: 103-7.

15. Hooton TM, Scholes D, Stapleton AE, Roberts PL, Winter C, Gupta K et al. A prospective study of asymptomatic bacteriuria in sexually active young women. N Engl J Med 2000; 343: 992-7.

16. Kunin CM, McCormack RC. An epidemiologic study of bacteriuria and blood pressure among nuns and working women. N Engl J Med 1968; 278: 635-42.

17. Nicolle LE. Asymptomatic bacteriuria: when to screen and when to treat. Infect Dis Clin North Am 2003; 17: 367-94.

18. Lipsky BA. Urinary tract infections in men. Epidemiology, pathophysiology, diagnosis, and treatment. Ann Intern Med 1989; 110: 138-50.

19. Jayawardena V, Midha M. Significance of bacteriuria in neurogenic bladder. J Spinal Cord Med 2004; 27: 102-5.

20. Lewis RI, Carrion HM, Lockhart JL, Politano VA. Significance of asymptomatic bacteriuria in neurogenic bladder disease. Urology 1984; 23: 343-7.

21. Epp A, Larochelle A, Lovatsis D, Walter JE, Easton W, Farrell SA et al. Recurrent urinary tract infection. J Obstet Gynaecol Can 2010; 32: 1082-90. 